\title{
The role of WWOX tumor suppressor gene in the regulation of EMT process via regulation of CDH1-ZEB1-VIM expression in endometrial cancer
}

\author{
ELŻBIETA PŁUCIENNIK ${ }^{1 *}$, MAGDALENA NOWAKOWSKA $^{1 *}$, KAROLINA POSPIECH $^{1}$, ANNA STEPIEN $^{2}$, \\ MATEUSZ WOŁKOWICZ ${ }^{3}$, MAŁGORZATA GAŁDYSZYŃSKA ${ }^{4}$, MARTA POPĘDA ${ }^{4}$, \\ KATARZYNA WÓJCIK-KROWIRANDA ${ }^{5}$, ANDRZEJ BIEŃKIEWICZ ${ }^{5}$ and ANDRZEJ K. BEDNAREK ${ }^{1}$
}

\begin{abstract}
${ }^{1}$ Department of Molecular Carcinogenesis, Medical University of Lodz; ${ }^{2}$ Laboratory of Clinical and Transplant Immunology and Genetics, Copernicus Memorial Hospital in Lodz; ${ }^{3}$ Bio-Tech Consulting Sp. z o.o, Faculty of Biomedical Science and

Postgraduate Education, Medical University of Lodz; ${ }^{4}$ Faculty of Biomedical Sciences and Postgraduate Education,

${ }^{5}$ Clinical Division of Gynecological Oncology, Medical University of Lodz, PL 90-752 Lodz, Poland
\end{abstract}

Received January 30, 2015; Accepted March 20, 2015

DOI: 10.3892/ijo.2015.2964

\begin{abstract}
This study defines the role of WWOX in the regulation of epithelial to mesenchymal transition. A group of 164 endometrial adenocarcinoma patients was studied as well as an ECC1 well-differentiated steroid-responsive endometrial cell line, which was transducted with WWOX cDNA by a retroviral system. The relationship between WWOX gene and EMT marker (CDHI, VIM, ZEBI, SNAII) expression on mRNA (RT-qPCR) and protein levels (western blotting) was evaluated. The EMT processes were also analysed in vitro by adhesion of cells to extracellular matrix proteins, migration through a basement membrane, anchorage-independent growth and MMP activity assay. DNA microarrays (HumanOneArray ${ }^{\mathrm{TM}}$ ) were used to determine $W W O X$-dependent pathways in an ECC1 cell line. A positive correlation was observed between $W W O X$ and $Z E B I$, and a negative correlation between $C D H I$ and VIM. WWOX expression was found to inversely correlate with the risk of recurrence of tumors in patients. However, in the WWOX-expressing ECC1 cell line, WWOX expression was found to be inversely related with VIM and positively with $C D H 1$. The ECC1/WWOX cell line variant demonstrated increased migratory capacity, with increased expression of metalloproteinases MMP2/MMP9. However, these cells were not able to form colonies in suspension and revealed decreased adhesion to fibronectin and fibrinogen. Microarray analysis demonstrated that $W W O X$ has an impact on the variety of
\end{abstract}

\footnotetext{
Correspondence to: DrElżbietaPłuciennik,Department of Molecular Carcinogenesis, Medical University of Lodz, Zeligowskiego 7/9, PL 90-752 Lodz, Poland

E-mail: elzbieta.pluciennik@umed.lodz.pl

*Contributed equally
}

Key words: WWOX, endometrial cancer, epithelial-mesenchymal transition, RT-qPCR cellular pathways including the cadherin and integrin signalling pathways. Our results suggest that the $W W O X$ gene plays a role in the regulation of EMT processes in endometrial cancer by controlling the expression of proteins associated with cell motility, thus influencing tissue remodeling, with the suppression of mesenchymal markers.

\section{Introduction}

Endometrial cancer is one of the most common malignant tumors of the reproductive tract among women in developed counties. In Poland in 2010, over five thousand women were diagnosed with endometrial cancer of whom over a thousand died (http://epid.coi.waw.pl/krn/). The average age at diagnosis is 65 , and mortality rate increases with the age of patient $(1,2)$. Many potential risk factors have been characterized, such as obesity, menopausal status, unopposed estrogens, low parity and nullparity and history of cancer in family (1-3) however, the mechanisms by which they work are not fully understood.

Moreover, conditions such as diabetes mellitus and polycystic ovarian syndrome increase the risk of endometrial cancer development (4). Most endometrial cancers are sporadic, and can be divided into two general groups based on histopathological features and molecular profiles: endometroid endometrial cancers (EECs) and non-endometroid endometrial cancers (NEECs) (1-3). Type I, or endometrioid endometrial cancers (EEC), are more common and characterized by estrogen-dependence, microsatellite instability, loss of heterozygosity of the PTEN tumor suppressor gene and genetic alterations in the RAS and WNT pathways. Type II, non-endometrioid endometrial cancers (NEECs), are characterized by estrogen-independence with an abnormal accumulation of $\mathrm{p} 53$ protein, inactivation of the p16 gene, overexpression of the HER2/neu gene and decreased expression of the $\mathrm{CDH} 1$ gene (5). However, it is important to note that the molecular pathways of the two cancer types are not fully understood. 
The epithelial-mesenchymal transition (EMT) is a complex process which results in transformation of epithelial to mesenchymal cells. Cells of the epithelium are characterized by polarity and non-motility, while mesenchymal cells are loosely organized and able to migrate (6-8). These features are a consequence of changes in gene expression profile i.e., increases in expression of mesenchymal markers such as vimentin and $\mathrm{N}$-cadherin, and donwregulation of epithelial markers such as E-cadherin and cytokeratins, which act as thigh and adherence junction proteins $(9,10)$. Although EMT is associated with embryogenesis and organ development under physiological conditions, it has also been associated with cancer progression and metastasis (10-12). A number of transcription factors, i.e., SNAI1, SNAI2, TWIST and ZEB1/2, which are known as the E-cadherin repressors, are the key regulators triggering EMT progression $(9,11,13)$. Changes in EMT marker expression are important in endometrial cancer, as cancer cells invade the myometrium, and this invasion is considered one of the most important prognostic factors for types I and II EC (14).

The WW domain-containing oxidoreductase gene (WWOX), also known as FOR or WOX1, is a tumor suppressor gene which spans more than one million base pairs mapped at locus 16q23.3-q24 in the common chromosomal fragile site FRA16D. The WWOX gene encodes a chain of 414 amino acids constituting a $46-\mathrm{kDa}$ protein containing two WW domains in the NH2-terminal region with a short-chain dehydrogenase/reductase domain, which suggests that it may interact with the receptors regulating steroid hormones. The first WW domain interacts with many partners such as ERBB4 $(15,16)$, transcription factor AP2 $\gamma(17,18)$, YAP (15), Jun (19), HIF1 $\alpha$ (20) and others (21). A high level of WWOX expression has been observed in hormone-dependent tissues such as those of the ovary, mammary gland or testis, which together with the enzymatic specificity of the SDR domain, indicates its role in the metabolism of steroid hormones $(22,23)$. Loss of WWOX expression has been observed during the development of various types of cancer. Moreover, numerous studies have demonstrated correlations between the decrease of WWOX expression and the presence of adverse prognostic factors, including shorter survival and a higher degree of malignancy in various types of carcinoma, especially such hormonedependent ones as those of the breast $(5,16,24)$, prostate $(25)$, ovary (26) and others (27-31). The suppressive character of the WWOX gene has been confirmed in many in vitro studies, where WWOX overexpression resulted in inhibition of cell proliferation, increased apoptosis and inhibition of anchorageindependent growth (32-34). Moreover, mice with a knocked out WWOX gene resulted in a greater incidence of numerous disorders such as bone metabolic defects, improper glandular development and disruption of steroidogenesis (23). However, the experiments performed in our laboratory on variety of tumor types, indicated that WWOX functioning in the cell appears to be more complex and is probably not only limited to well-known tumor suppressor properties.

We redirected our interest into WWOX regulation of cell adhesion and motility properties, as Gourley et al reported that overexpression of WWOX in an ovarian cancer cell line resulted in decreased adhesion to fibronectin (35), and WWOX ectopic overexpression in breast cancer and colon cancer cell lines has also been observed to result in increased potential of invasion with the modulation of cell adhesive properties $(36,37)$. Moreover, in our previous study on endometrial cancer, we observed that $W W O X$ negatively correlated with $C D H 1$ expression, a well known epithelial marker downregulated during EMT (38). The aim of the study, as a continuation of previous observations, was to determine its role in the EMT process using both an in vitro model and endometrial tumor samples.

The overexpression of WWOX in an ECC1 well-differentiated steroid-responsive endometrial cell line was induced via stable retroviral transduction. The changes in global gene expression profile after WWOX induction were assessed by microarray and the biological effects connected with EMT process were assessed by migration through a basement membrane, anchorage-independent growth, adhesion to ECM proteins and MMPs activity. RT-qPCR analysis of chosen EMT markers was also performed on 164 tumor samples.

\section{Materials and methods}

Tumor samples. The study included 164 endometrioid endometrial carcinomas (EECs, type I) obtained from the Department of Gynecological Oncology, Medical University of Lodz. The samples were classified according to FIGO classification system and also classified into risk of recurrence category according to Pecorelli (39). The mean age was 62 years (median 61; range 31-83 years). Tumor samples were stored at $-80^{\circ} \mathrm{C}$ in RNA Later buffer (Ambion ${ }^{\circledR}$; Thermo Fisher Scientific, Waltham, MA, USA).

The study was performed after receiving the consent of the patients, and was approved by the the Ethics Committee of the Medical University of Lodz (RNN/208/11/KE).

Cell lines and reagents. The ECC-1 cell line was obtained from the American Type Culture Collection (ATCC). This endometrial cancer cell line is hormone-responsive, as well as estrogen ( $\alpha$ and $\beta)$, androgen and progesterone receptorpositive (40). Cells were cultured in advanced RPMI-1640 medium supplemented with heat-inactivated fetal bovine serum (Invitrogen Life Technologies, Carlsbad, CA, USA), L-glutamine (Invitrogen Life Technologies), HEPES buffer (Invitrogen Life Technologies) and antibiotics (penicillin $50 \mathrm{U} / \mathrm{ml}$; streptomycin $50 \mu \mathrm{g} / \mathrm{ml}$; neomycin $100 \mu \mathrm{g} / \mathrm{ml}$ ) (Invitrogen Life Technologies). The cells were incubated at $37^{\circ} \mathrm{C}$ in a humidified incubator with $5 \% \mathrm{CO}_{2}$.

Transduction. The process was performed with retroviral vector pLNCX2, either with or without WWOX cDNA. To increase the effectiveness of transduction, the infectious medium was supplemented with $8 \mu \mathrm{g} / \mathrm{ml}$ polybrene (Sigma-Aldrich, MO, USA). After $24 \mathrm{~h}$, the medium was removed and replaced with advanced RPMI-1640 (Invitrogen Life Technologies) with standard supplements. For selection, the cells were cultured in the presence of $400 \mathrm{mg} / \mathrm{ml} \mathrm{G} 418$ (Sigma-Aldrich) for 14 days. The stable transductants were analyzed by RT-qPCR and western blot assay.

$R T-q P C R$. Total RNA from cells and tumor tissues was isolated using TRIzol reagent (Invitrogen Life Technologies), 
and $10 \mu \mathrm{g}$ of RNA was reverse-transcribed with ImProm RT-II reverse transcriptase (Promega Corp., Madison, WI, USA).

RT-qPCR was performed with LightCycler 480 II (Roche Diagnostics GmbH, Mannheim, Germany). PCR products were detected with SYBR Green I and qPCR Core kit for SYBR Green I (Eurogentec, Southampton, UK). Reactions were performed in duplicate. The relative expression of $W W O X, C D H 1$, and VIM were analysed, as were two $C D H I$ repressors: $Z E B 1$ and $S N A I 1$. The relative expression of all investigated genes was normalized to three reference genes: RPLPO, RPS17 and H3F3A. All information regarding primer sequences, $\mathrm{PCR}$ reaction conditions and the length of received products is available upon request. The relative expression level of all investigated genes was calculated using the Roche algorithm (41) with the Universal Human Reference RNA (Stratagene, La Jolla, CA, USA) as a calibrator.

Microarray assay. The microarrays were performed using Human OneArray Whole Genome Microarray v 5.1 (Phalanx Biotech, USA) in four replicates (dual labelling protocol). A ULS $^{\text {TM }}$ Labeling kit (Kreatech Diagnostics, The Netherlands) was used to alternately/cross label single-stranded cDNA of two variants (ECC1/vector, ECC1/WWOX) with Cy3 and Cy5 as well as Universal Human Reference RNA (Stratagene).

The slide was prepared for hybridization and prehybridization according to the manufacturer's protocol. The hybridization process was performed in a $2 \mathrm{X}$ SSPE humidity chamber at $42^{\circ} \mathrm{C}$ for $16-18 \mathrm{~h}$. The following buffers were used for post-hybridization washes: $1 \mathrm{X} \mathrm{SSPE} / 0.03 \%$ SDS (2 min, $42^{\circ} \mathrm{C}$ ), $1 \mathrm{X}$ SSPE (2 min, RT), 0.1X SSPE (rinsed several times, RT) (Phalanx Biotech).

ProScanArray (Perkin-Elmer, USA) was used for scanning and ScanArray Express for preliminary normalization. Lowess and statistical analysis were performed with TM4 software suite provided by The Institute for Genomic Research (http:// www.tm4.org/). After modified t-test analysis, the fold change was calculated and the Pantherdb online ontology application (www.pantherdb.org) was used to classify the received genes according to ontological terms. The results were regarded as significant at $\mathrm{p}<0.05$.

Protein extraction and western blotting. The endometrial cancer cells were lysed in RIPA protein extraction buffer supplemented with proteases, phosphatase inhibitor cocktail and PMSF (Sigma-Aldrich). The protein concentration was measured using the Bradford method (Bio-Rad Laboratories, CA, USA), run on 10\% SDS-PAGE gel electrophoresis and transferred to a PVDF membrane (Sigma-Aldrich). The membranes were blocked in a buffer of 5\% non-fat milk in TBST for $1 \mathrm{~h}$ at room temperature and then incubated for $19 \mathrm{~h}$ at $4^{\circ} \mathrm{C}$ with primary antibodies to goat anti-human WWOX, 1:100; mouse anti-E-cadherin, 1:100; mouse anti-vimentin, 1:100 (sc:20529, sc:8426, sc:51721, Santa Cruz Biotechnology Inc., Dallas, TX, USA). Following incubation, the membranes were washed three times with TBST and incubated with secondary antibodies conjugated with alkaline phosphatase (Sigma-Aldrich) for $1 \mathrm{~h}$. The membranes were washed three times in TBST and developed using Novex ${ }^{\circledR}$ AP Chromogenic Substrate (Invitrogen Life Technologies). Glyceraldehyde-3phosphate dehydrogenase (GAPDH) at a dilution of 1:1,000 was used as the reference protein (sc-59540, Santa Cruz Biotechnology Inc.). All biological tests were performed in a minimum of three replicates.

Adhesion assay. Cell adhesion was evaluated using Cell Biolabs CytoSelect ${ }^{\mathrm{TM}}$ Cell Adhesion assay kit (Cell BioLabs, San Diego, CA, USA) according to the manufacturer's instructions. This test provides a rapid and quantitative method for accessing the cell adhesion potential. The ECC1 cells were seeded at a density of $1.5 \times 10^{5}$ cells in a total volume of $150 \mu \mathrm{l}$ serum-free media to each well. The cells were incubated for $1 \mathrm{~h}$ at $37^{\circ} \mathrm{C}$. The absorbance was measured at $560 \mathrm{~nm}$ with a BioTek plate reader (BioTek US, USA).

Cell invasion assay. The cell invasiveness potential was determined using a Colorimetric CytoSelect ${ }^{\mathrm{TM}}$ Cell Invasion Assay Kit Cell (Cell BioLabs) according to the manufacturer's protocol. The cell suspension was incubated at a density of $3 \times 10^{5} /$ well in serum-free media for $48 \mathrm{~h}$. The absorbance was measured at $560 \mathrm{~nm}$ on a BioTek reading plate (BioTek US). Each variant was tested in quadruplicate.

Zymography. ECC1 cells were seeded in 6-well plates at a density of $1.5 \times 10^{6} /$ well. Twenty-four hours before collection, the medium was replaced with serum-free RPMI medium. Qubit ${ }^{\circledR}$ Protein assay kits (Invitrogen Life Technologies) were used to quantify protein content. Samples containing $15 \mu \mathrm{g}$ of protein were separated in $10 \%$ SDS-page gel containing $2 \mathrm{mg} /$ $\mathrm{ml}$ gelatin. After electrophoresis, the gel was washed twice for 30 min in $2.5 \%$ Triton $\mathrm{X}-100$ wash buffer and then incubated at $37^{\circ} \mathrm{C}$ for $18 \mathrm{~h}$ in a solution containing $50 \mathrm{mM}$ Tris $(\mathrm{pH} \mathrm{7.5)}$ (Sigma-Aldrich), $10 \mathrm{mM} \mathrm{CaCl}_{2}$ (Sigma-Aldrich) and $200 \mathrm{mM}$ $\mathrm{NaCl}$ (Sigma-Aldrich). Following this, the gel was stained with $0.125 \%$ Coomassie brilliant blue R-250 (Sigma-Aldrich) and de-stained with solution (30\% methanol, $10 \%$ acetic acid, $60 \%$ distilled water) (Sigma-Aldrich). A protein marker was used to measure the molecular weights of the analysed enzymes. Densitometric analysis with ImageJ Analysis 1.34s software (Wayane Rasband, National Institutes of Health, USA, http://rsb.info.nih.gov/ij/) was used to quantify MMP activities.

Soft agar. A soft agar assay was performed to analyze the differences in anchorage-independent growth between ECC1/WWOX and ECC1/vec. Six-well plates were coated with $2 \mathrm{ml} \mathrm{0.9 \%}$ low melting agarose (AppliChem, MO, USA) in RPMI-1640 with $10 \%$ FBS. Both variants of ECC1 cells were suspended in $0.3 \%$ low melting agarose at a concentration of $10^{4}$ cells per well. The cells were incubated at $37^{\circ} \mathrm{C}$ in a humidified incubator for 14 days. The plates were stained with $1 \mathrm{ml}$ of $0.005 \%$ crystal violet (Sigma-Aldrich) in water and colonies were counted using ImageJ Analysis $1.34 \mathrm{~s}$ software (Wayane Rasband, National Institutes of Health, USA, http:// rsb.info.nih.gov/ij/).

Statistical analysis. The correlation of expression was performed using the non-parametric Spearman's rank correlation test. The Mann-Whitney t-test was used to determine the differences between the levels of expression of the investigated genes and clinical factors in patients with endometrial cancer. 


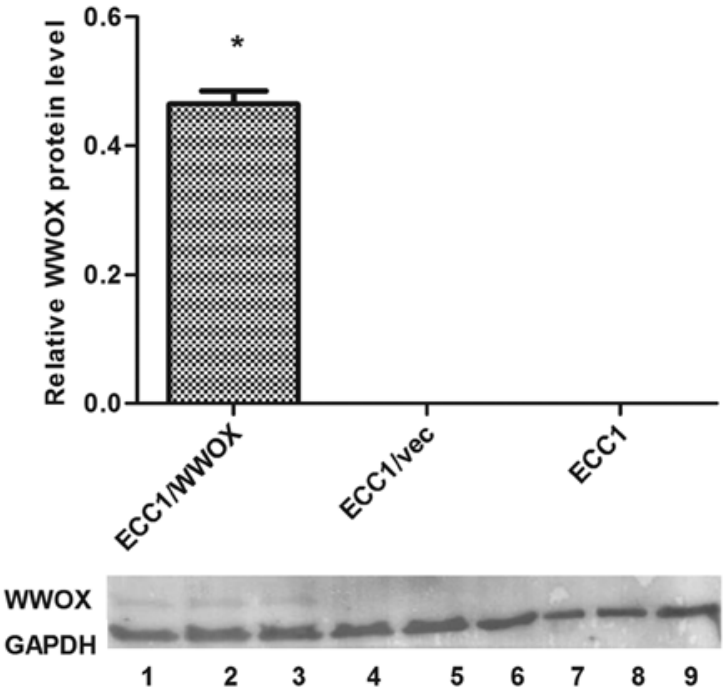

Figure 1. Confirmation of ECC1 cell line transfection on the protein level. The values are mean $\pm \mathrm{SD}$. " $\mathrm{p}<0.05$. Lanes 1-3, ECC1/WWOX; lanes 4-6, $\mathrm{ECC1} / \mathrm{vec}$; lanes 7-9, ECC1.

The Aspin-Welsch t-test was used to determine the statistical significance of the difference observed between cell variants in all biological tests.

\section{Results}

Confirmation of WWOX gene transduction in ECCl. The transduction resulted in the increase of WWOX expression both on the mRNA and protein levels. A $>180$-fold change of WWOX gene expression was observed on the mRNA level: the mean relative expression values being 0.019 and 3.34 for $\mathrm{ECC} 1 /$ vector and $\mathrm{ECC} 1 / \mathrm{WWOX}$ respectively. The change on the protein level is shown (Fig. 1).

Microarray analysis. Our microarray analysis revealed more than 800 genes with changed expression as the result of $W W O X$ ectopic overexpression $(\mathrm{p}<0.05)$. The identified genes belong to several signalling pathways associated with regulation of cell differentiation, apoptosis and cellular communication/ tissue architecture (Table I). The predominant ones being the Wnt signalling pathway (13 genes), integrin signalling pathway (10 genes), inflammation mediated by chemokine and cytokine signalling pathway (6 genes), gonadotropinreleasing hormone receptor pathway (11 genes), angiogenesis (6 genes), TGF- $\beta$ signalling pathways ( 8 genes), apoptosis (5 genes), and the cadherin signaling pathway (6 genes). The ontology classification (by cellular pathways) by $W W O X$ overexpression is included in Table II. The two main EMT markers found in the cadherin signalling pathway were vimentin and E-cadherin.

A 1.6-fold increase in expression of the $\mathrm{CDH} 1$ gene and a 1.9-fold decrease in expression of VIM mRNA were observed in the ECC1 cell line overexpressing WWOX. Microarray data were submitted to the GEO Database (reference series: GSE61041).

Microarray validation. The observed change in expression of $C D H 1$ and VIM was confirmed with RT-qPCR: a 3.5-fold
Table I. Ontological analysis of genes in biological process regulated by WWOX gene in ECC1 cell line.

\begin{tabular}{|c|c|}
\hline Biological process & No. of genes \\
\hline Metabolic process & 368 \\
\hline Primary metabolic process & 299 \\
\hline Unclassified & 266 \\
\hline Cellular process & 262 \\
\hline Cell communication & 147 \\
\hline Biological regulation & 138 \\
\hline $\begin{array}{l}\text { Nucleobase-containing compound metabolic } \\
\text { process }\end{array}$ & 138 \\
\hline Protein metabolic process & 136 \\
\hline Localization & 124 \\
\hline Transport & 120 \\
\hline Developmental process & 117 \\
\hline RNA metabolic process & 102 \\
\hline Regulation of biological process & 87 \\
\hline Transcription, DNA-dependent & 82 \\
\hline $\begin{array}{l}\text { Transcription from RNA polymerase II } \\
\text { promoter }\end{array}$ & 80 \\
\hline Multicellular organismal process & 70 \\
\hline Single-multicellular organism process & 70 \\
\hline $\begin{array}{l}\text { Regulation of nucleobase-containing } \\
\text { compound metabolic process }\end{array}$ & 69 \\
\hline System development & 69 \\
\hline Cell cycle & 68 \\
\hline Response to stimulus & 65 \\
\hline Immune system process & 62 \\
\hline $\begin{array}{l}\text { Regulation of transcription from RNA } \\
\text { polymerase II promoter }\end{array}$ & 62 \\
\hline Cellular protein modification process & 61 \\
\hline Protein transport & 60 \\
\hline Intracellular protein transport & 60 \\
\hline System process & 60 \\
\hline Regulation of catalytic activity & 51 \\
\hline Regulation of molecular function & 51 \\
\hline Neurological system process & 48 \\
\hline Cellular component organization or biogenesis & 46 \\
\hline Cellular component organization & 43 \\
\hline Mesoderm development & 43 \\
\hline Nervous system development & 42 \\
\hline Ectoderm development & 42 \\
\hline Cell adhesion & 41 \\
\hline Biological adhesion & 41 \\
\hline Cell-cell signaling & 41 \\
\hline Anatomical structure morphogenesis & 28 \\
\hline Cell-cell adhesion & 27 \\
\hline Cellular component morphogenesis & 26 \\
\hline Death & 26 \\
\hline Cell death & 26 \\
\hline Apoptotic process & 26 \\
\hline Mitosis & 26 \\
\hline
\end{tabular}


Table II. The number of genes in pathways regulated by WWOX gene in ECC1 cell line.

\begin{tabular}{lc}
\hline Pathway & No. of genes \\
\hline Unclassified & 667 \\
Wnt signalling pathway & 13 \\
Gonadotropin-releasing hormone & 11 \\
receptor pathway & \\
Integrin signalling pathway & 10 \\
TGF- $\beta$ signalling pathway & 8 \\
Alzheimer disease-presenilin pathway & 7 \\
Angiogenesis & 6 \\
Inflammation mediated by chemokine and & 6 \\
cytokine signalling pathway & \\
Huntington disease & 6 \\
Cadherin signalling pathway & 6 \\
Apoptosis signalling pathway & 5 \\
Heterotrimeric G-protein signalling & 5 \\
pathway-Gq $\alpha$ and Go $\alpha$ mediated pathway &
\end{tabular}

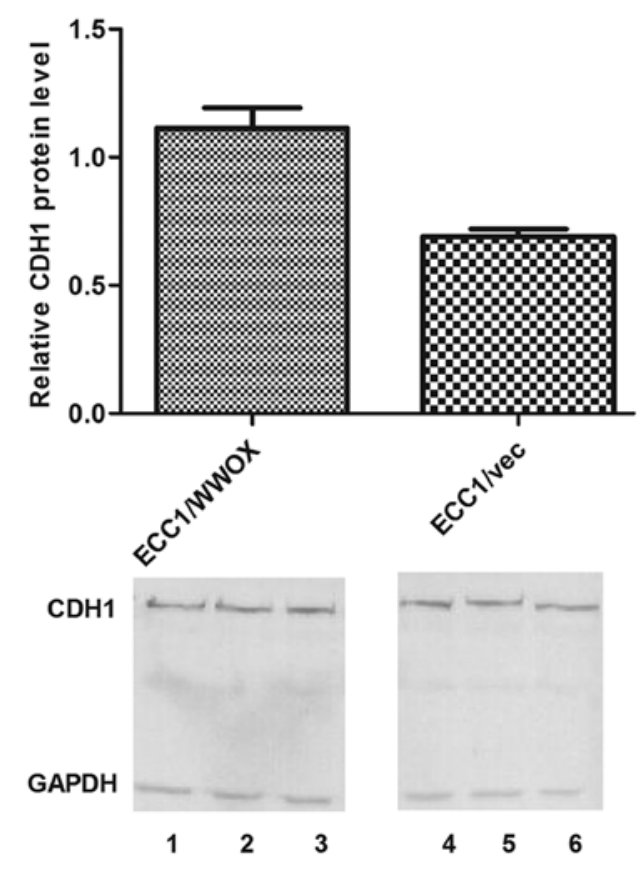

Figure 2. Western blot analysis of the level of $\mathrm{CDH} 1$ protein. The values are mean \pm SD. Lanes 1-3, ECC1/WWOX; lanes 4-6, ECC1/vec.

increase of $C D H 1$ (mean relative expression 0.48 vs 1.67 for $\mathrm{ECC1}$ /vector and $\mathrm{ECC1} / \mathrm{WWOX}$ respectively); 2-fold decrease for VIM (0.00035 vs 0.00019 for ECC1/vector and ECC1/ WWOX respectively). Similar changes were also noted on protein level (Figs. 2 and 3).

The influence of WWOX on invasiveness, adhesion potential and cell growth in suspension. Overexpression of the WWOX gene resulted in a 1.3 -fold increase in migration in comparison to the $\mathrm{ECC} 1 / \mathrm{vector}(\mathrm{p}<0.05)$ (Fig. 4$)$ and greater induction of metalloproteinase activity i.e., MMP-2 and -9 (Fig. 5). These
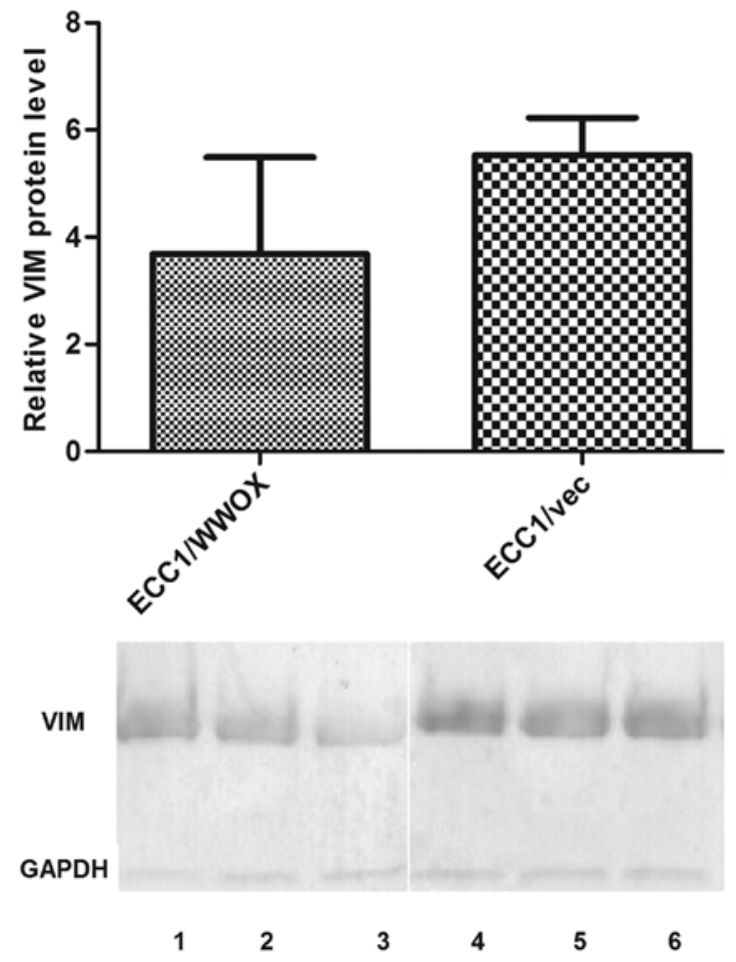

Figure 3. Western blot analysis of the level of VIM protein. The values are mean $\pm \mathrm{SD}$. Lanes 1-3, ECC1/WWOX; lanes 4-6, ECC1/vec.

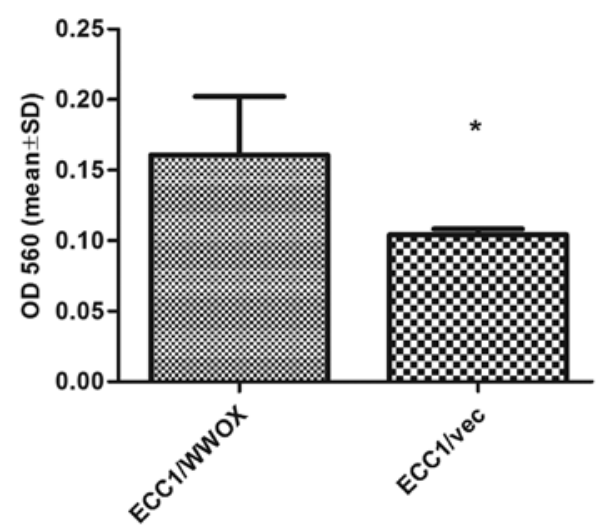

Figure 4 . The ability to cross a membrane coated with a basement membrane matrix of ECC1/WWOX. The values are mean $\pm \mathrm{SD}$. ${ }^{*} \mathrm{p}<0.05$.

results suggest that increased expression of WWOX influences the motility and invasive potential of the cells. However, the soft agar assay, which measures the ability of cells to grow in suspension, in a similar way to cancer cells being able to survive after detachment, revealed a reduced colony number for the ECC1/WWOX cell line variant (Fig. 6, p $<0.05$ ).

The invasion and growth in soft agar assay results indicate that even though ECC1/WWOX cells demonstrated a higher basic membrane transition ability, they were unable to survive after detachment. The cells overexpressing WWOX demonstrated a significantly lower ability to adhere to fibrinogen (1.8-fold change; $p<0.05$ ) (Fig. 7).

Expression analysis in tumor samples. In the tumor samples, the EMT markers were also analyzed in relation to WWOX. 

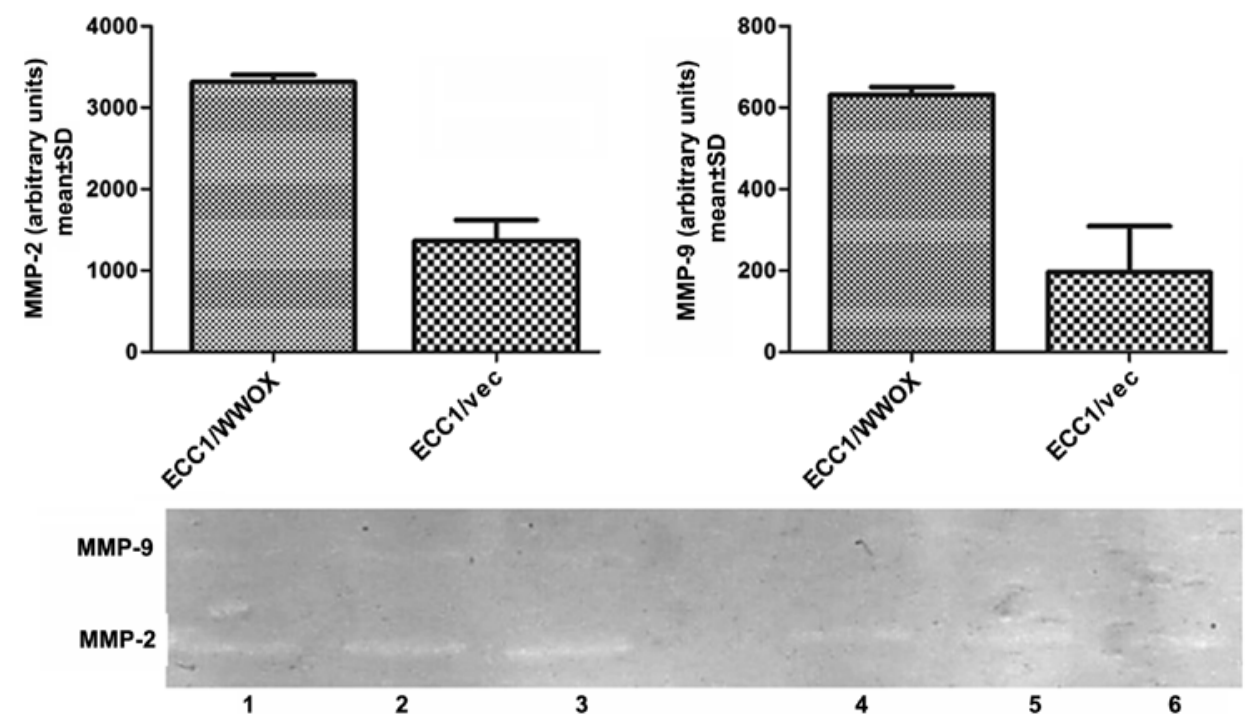

Figure 5. MMP-2 and MMP-9 activities analyzed by gelatin zymography of ECC1/WWOX. The values are mean \pm SD. Lanes 1-3, ECC1/WWOX; lanes 4-6, $\mathrm{ECC} 1 / \mathrm{vec}$.

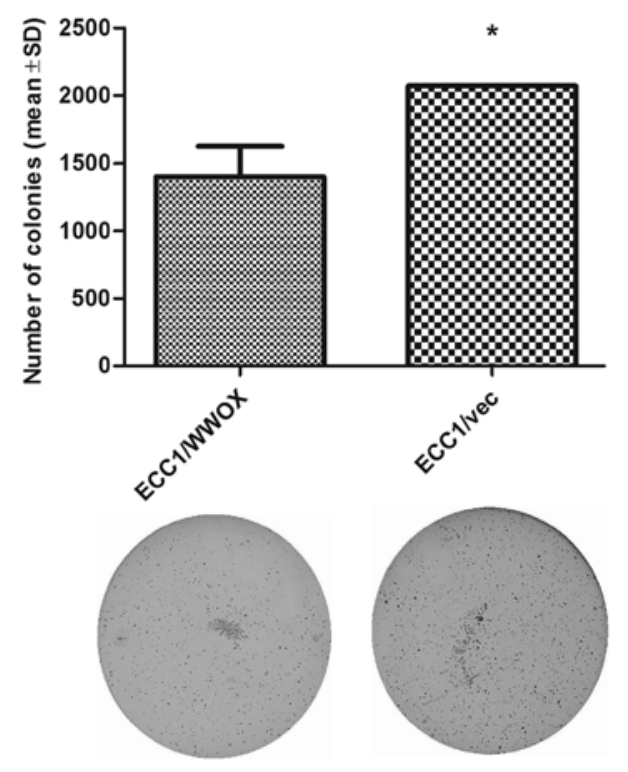

Figure 6. Colony formation assays of ECC1/WWOX. The colonies were counted using ImageJ software (mean $\pm \mathrm{SD}) .{ }^{*} \mathrm{p}<0.05$.

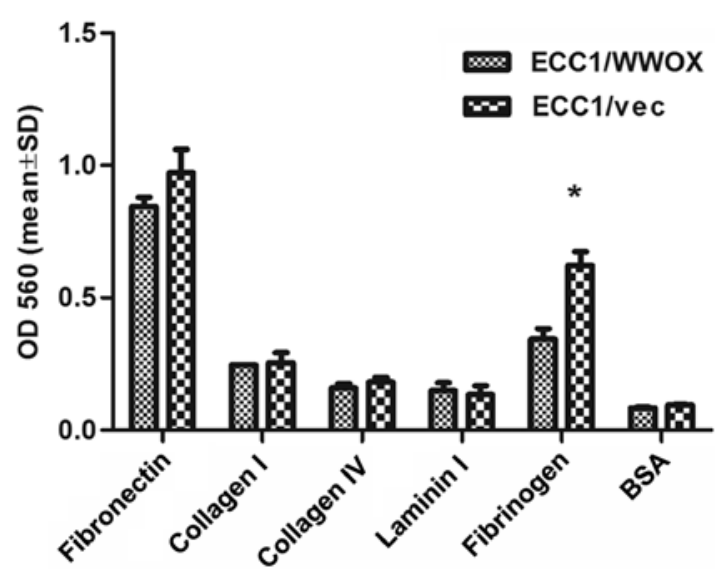

Figure 7. Adhesion to ECM proteins of ECC1/WWOX and ECC1/vec control cells. The values are mean $\pm \mathrm{SD}$. " $\mathrm{p}<0.05$, BSA, bovine serum abumin.
Table III. The correlation analysis between the levels of expression of WWOX and other EMT tumor-related genes in endometrial carcinoma patients.

\begin{tabular}{lcc}
\hline Gene & $\begin{array}{c}\text { Spearman's rank } \\
\text { correlation }\end{array}$ & P-value \\
\hline WWOX/VIM & $\mathbf{- 0 . 2 6 8}$ & 0.0005 \\
WWOX/ZEB1 & $\mathbf{0 . 2 6 0}$ & $\mathbf{0 . 0 0 0 4}$ \\
WWOX/CDH1 & $\mathbf{- 0 . 5 1 2}$ & $\mathbf{0 . 0 0 0 1}$ \\
WWOX/SNAII & 0.029 & 0.7114 (NS) \\
\hline
\end{tabular}

ZEBI and SNAII were included in the EMT marker gene panel. A positive correlation was observed between $W W O X$ and ZEBI $\left(\mathrm{R}_{\mathrm{s}}=0.26 ; \mathrm{p}=0.0004\right)$, and a negative correlation between $W W O X$ and $V I M\left(\mathrm{R}_{\mathrm{s}}=-0.268, \mathrm{p}=0.0005\right)$. A negative correlation is known to exist between $W W O X$ and $C D H 1$ (38) and this was confirmed by the increased number of samples. The correlation with SNAI1 was statistically insignificant $\left(R_{s}=0.029 ; p>0.05\right)$. The remaining correlations are presented in Table III. Similar to other tumor types, the expression of WWOX in endometrial cancer inversely correlated with the risk of cancer recurrence, i.e., tumors with low risk demonstrated higher WWOX expression than those with medium and high risk. A statistically significant difference was found between the low $(\mathrm{n}=38$, median expression 2.33$)$ and medium $(\mathrm{n}=83$, median expression 1.12) risks of disease recurrence $(\mathrm{p}=0.023)$. More detailed information of all correlations with clinical factors is presented in Table IV.

\section{Discussion}

The process of epithelial to mesenchymal transition and its regulation seems to be important in endometrial carcinogenesis and disease progression. A review of the literature indicates that this is the first report to investigate the influence 


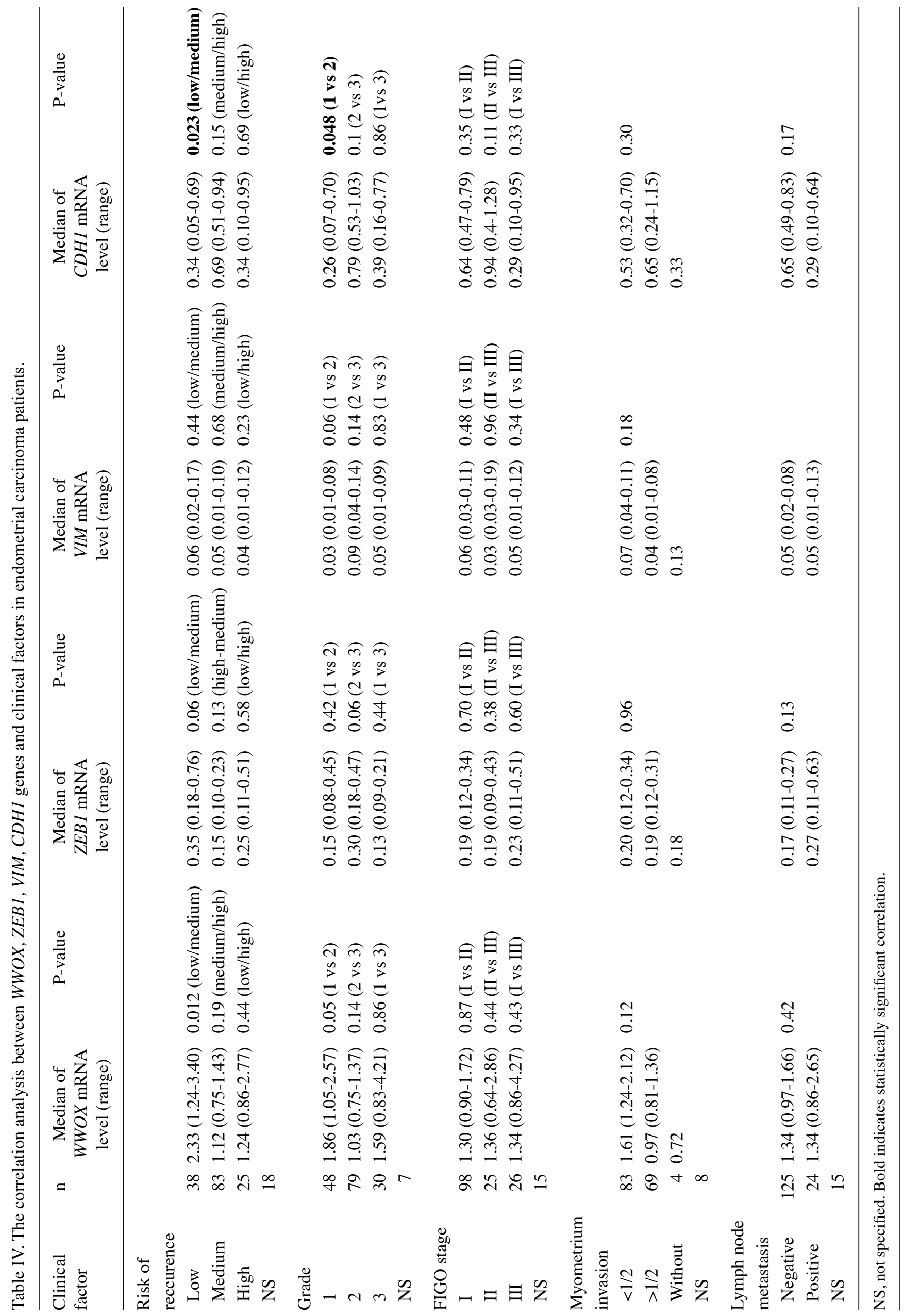


of the WWOX gene on EMT in endometrial tumor samples and in an endometrial cancer cell line model.

The present study is a continuation of previous observations that $W W O X$ inversely correlates with $C D H 1$ expression, which suggests that alterations in the expression of this tumor suppressor gene probably influence the process of cell adhesion (38).

WWOX overexpression was induced in a well-differentiated endometrial cancer cell line and its effect on EMT progression was analysed on microarrays and by multiple biological assays. The microarray analysis revealed significant changes $(\mathrm{p}<0.05)$ in the expression of two main EMT markers, oppositely regulated in relation to $W W O X$ expression level i.e., $C D H 1$ was upregulated and VIM was downregulated. This result was confirmed on both the protein and mRNA levels.

This observed upregulation of $C D H 1$ in the cancer cell line stands in contrast to our previous report, which revealed a negative correlation between $C D H 1$ and $W W O X$. However, in the present study, the larger, tumor sample population also demonstrated a negative correlation. This discrepancy between the cell line model and the tumor samples in the present study may be explained by comparing the complexity of tumor architecture between the ECM matrix and the cell line in a $2 \mathrm{D}$ in vitro culture. The well-differentiated nature of the cell line within the experiment may also have an impact on $W W O X$ functioning, as shown in previous studies on colon cancer cell lines (36). However, the relationship between $C D H 1$ and $W W O X$ implies that the WWOX gene has an influence on the regulation of the adhesion process. The loss of E-cadherin expression is a hallmark of EMT, and its reduced transcription in endometrial cancer was found to correlate with the depth of myometrial invasion $(14,42)$.

In the increased number of tumor samples used in the present study, loss of $\mathrm{CDH} 1$ expression tended to be observed in grade 3 tumors and those with the highest risk of recurrence ( $p>0.05$ ). However, interestingly, grade 2 tumors and those with medium risk of recurrence demonstrated significantly higher $C D H 1$ expression on the mRNA level in comparison to grade 1 tumors and those with a low risk of recurrence.

WWOX mRNA expression was found to have an inverse association with risk of recurrence and tumor grade. Tumors with low risk of recurrence and grade 1 demonstrated significantly higher WWOX expression, which confirms that loss of $W W O X$ is connected with tumor progression, as seen in other tumor types $(30,43,44)$. The inverse correlation with WWOX and $C D H 1$ seen in tumor samples may also suggest $W W O X$ regulatory role in the process of differentiation, since reduced $\mathrm{CDH} 1$ protein level is associated with diminished differentiation (42).

Even though the overexpression of $W W O X$ resulted in the increase of $C D H 1$ expression in the in vitro model, the result of the invasion assay revealed that the ECC1/WWOX cell line variant had increased invasion capacity and migratory potential, as overexpression of $W W O X$ resulted in increased expression of metalloproteinases MMP2/MMP9. This observation is consistent with previous findings in breast and colon cancer cell lines ectopically overexpressing WWOX protein $(36,37)$, but also implies that the interaction between WWOX and CDH1 may be modulated by other EMT-related genes. Hence, WWOX expression was compared with ZEBI and
SNAIL1 expression on the mRNA level. Of those two genes, a positive correlation was only noticed between $W W O X$ and ZEBI.

The observed positive correlation between $W W O X$ and ZEBI may further confirm the idea that WWOX may play a important role in EMT induction in terms of cell remodelling, with suppressed acquisition of the mesenchymal phenotype; this negative correlation was previously noted with vimentin, a mesenchymal marker, both in an in vitro model and in tumor samples.

In a normal human uterus, $Z E B 1$ expression is regulated by steroid hormones. It is higher in both stroma and the myometrium in the secretory phase than in the proliferative phase. While the $Z E B 1$ gene is silenced in the normal endometrial epithelium (45), it is expressed in the tumor-associated stroma of endometrial cancers, as well as in epithelial-derived cancer cells, with its level correlating with disease staging $(45,46)$. Thus, activation of $Z E B 1$ expression in epithelial cancer cells causes EMT, through repression of $C D H 1$ and induction of vimentin (46). In the present study, especially in tumor samples, it seems that the negative correlation between $W W O X$ and $C D H 1$ may be a result of $Z E B 1$ interplay in the functional axis of WWOX-CDH1, and is not present in the stable microenvironment of cell culture.

However, ZEB1-regulated acquisition of mesenchymal phenotype was found to be incompleted in both the in vitro model and tumor samples. High $W W O X$ expression resulted in decreased VIM expression. This negative correlation was confirmed on the protein level in the in vitro ECC1 cultures and has recently also been observed for ovarian cancer (47). The possibility that mesenchymal progression was incomplete as a result of VIM downregulation is confirmed by the observation that the $W W O X$-transducted cells were not able to form colonies in suspension, suggesting that they have lost some of their aggressiveness. This observation is consistent with previous findings on ovarian and cervical cancer cell lines $(32,33)$ and confirms the tumor suppression properties of $W W O X$. Moreover, our findings also support those of Gourley et al that WWOX may be involved in tissue architecture organization through modulation of the adhesion potential of cells to different ECM proteins (35). Significantly reduced adhesion to fibrinogen and tendency to fibrinonectin was demonstrated by ECC1 cells with high ectopic expression of WWOX.

The received tendency for decreased adhesion to fibronectin is consistent with previous findings in ovarian cancer (35), but this is the first study to reveal reduced adhesion to fibrinogen after $W W O X$ overexpression. Importantly, it has been hypothesized that fibrinogen is able to facilitate metastasis by enhancing adhesion, thus promoting the survival of tumor cells circulating in blood vessels. Elevated fibrinogen expression was associated with metastasis in lung, colon, ovarian and breast cancers $(48,49)$. Moreover, in breast cancer, fibrinogenmediated migration was observed only in such malignant tumor cell lines as MDA-MB-231 and MCF-7, whereas this ability was decreased in the non-malignant MCF-10A cell line (49). Hence, our observations on the endometrial cancer cell line seems to confirm that WWOX overexpression mediates the loss of aggressiveness and that this gene is involved in the regulation of adhesion potential. 
In conclusion, this study investigated the role of the WWOX gene in the process of EMT in endometrial cancer. On both tumor and cell line models, statistically significant correlations were noted with $\mathrm{CDH} 1$ and vimentin, which are the main markers of EMT. Our observations indicate that WWOX may be involved in the initiation of EMT, leading to changes in cell adhesion and motility. They also suggest that $W W O X$ plays a suppressive role in the process of mesenchymal phenotype acquisition, resulting in reduction of cell features associated with aggressiveness. However, further research in this direction is required.

\section{Acknowledgements}

We acknowledge Dr hab Agnieszka Piastowska-Ciesielska for access to BioTek reading plate and methodological support to western blot assay. This study was supported by the National Center of Sciences N N407 168940.

\section{References}

1. Amant F, Moerman P, Neven P, Timmerman D, Van LE and Vergote I: Endometrial cancer. Lancet 366: 491-505, 2005.

2. Leslie KK, Thiel KW, Goodheart MJ, De Geest K, Jia Y and Yang S: Endometrial cancer. Obstet Gynecol Clin North Am 39: 255-268, 2012.

3. Merritt MA and Cramer DW: Molecular pathogenesis of endometrial and ovarian cancer. Cancer Biomark 9: 287-305, 2010.

4. Troisi R, Potischman N, Hoover RN, Siiteri P and Brinton LA: Insulin and endometrial cancer. Am J Epidemiol 146: 476-482, 1997.

5. Bednarek AK, Laflin KJ, Daniel RL, Liao Q, Hawkins KA and Aldaz CM: WWOX, a novel WW domain-containing protein mapping to human chromosome $16 \mathrm{q} 23.3-24.1$, a region frequently affected in breast cancer. Cancer Res 60: 2140-2145, 2000.

6. Thiery JP, Acloque H, Huang RY and Nieto MA: Epithelialmesenchymal transitions in development and disease. Cell 139: 871-890, 2009.

7. Garg M: Epithelial-mesenchymal transition - activating transcription factors - multifunctional regulators in cancer. World J Stem Cells 5: 188-195, 2013.

8. Kalluri R and Weinberg RA: The basics of epithelial-mesenchymal transition. J Clin Invest 119: 1420-1428, 2009.

9. Tanaka Y, Terai Y, Kawaguchi H, Fujiwara S, Yoo S, Tsunetoh S, Takai M, Kanemura M, Tanabe A and Ohmichi M: Prognostic impact of EMT (epithelial-mesenchymal-transition)-related protein expression in endometrial cancer. Cancer Biol Ther 14: 13-19, 2013.

10. Huber MA, Kraut $\mathrm{N}$ and Beug H: Molecular requirements for epithelial-mesenchymal transition during tumor progression. Curr Opin Cell Biol 17: 548-558, 2005.

11. Thiery JP: Epithelial-mesenchymal transitions in development and pathologies. Curr Opin Cell Biol 15: 740-746, 2003.

12. Grünert S, Jechlinger $M$ and Beug $H$ : Diverse cellular and molecular mechanisms contribute to epithelial plasticity and metastasis. Nat Rev Mol Cell Biol 4: 657-665, 2003.

13. Montserrat N, Mozos A, Llobet D, Dolcet X, Pons C, de Herreros AG, Matias-Guiu X and Prat J: Epithelial to mesenchymal transition in early stage endometrioid endometrial carcinoma. Hum Pathol 43: 632-643, 2012.

14. Abal M, Llauradó M, Doll A, Monge M, Colas E, González M, Rigau M, Alazzouzi H, Demajo S, Castellví J, et al: Molecular determinants of invasion in endometrial cancer. Clin Transl Oncol 9: 272-277, 2007.

15. Aqeilan RI, Donati V, Palamarchuk A, Trapasso F, Kaou M, Pekarsky Y, Sudol M and Croce CM: WW domain-containing proteins, WWOX and YAP, compete for interaction with ErbB-4 and modulate its transcriptional function. Cancer Res 65 : 6764-6772, 2005.

16. Aqeilan RI, Donati V, Gaudio E, Nicoloso MS, Sundvall M, Korhonen A, Lundin J, Isola J, Sudol M, Joensuu H, et al: Association of Wwox with ErbB4 in breast cancer. Cancer Res 67: 9330-9336, 2007.
17. Aqeilan RI, Palamarchuk A, Weigel RJ, Herrero JJ, Pekarsky Y and Croce CM: Physical and functional interactions between the Wwox tumor suppressor protein and the AP-2gamma transcription factor. Cancer Res 64: 8256-8261, 2004.

18. Guler G, Huebner K, Himmetoglu C, Jimenez RE, Costinean S, Volinia S, Pilarski RT, Hayran M and Shapiro CL: Fragile histidine triad protein, WW domain-containing oxidoreductase protein Wwox, and activator protein 2gamma expression levels correlate with basal phenotype In breast cancer. Cancer 115: 899-908, 2009.

19. Gaudio E, Palamarchuk A, Palumbo T, Trapasso F, Pekarsky Y, Croce CM and Aqeilan RI: Physical association with WWOX suppresses c-Jun transcriptional activity. Cancer Res 66: 11585-11589, 2006.

20. Abu-Remaileh M and Aqeilan RI: Tumor suppressor WWOX regulates glucose metabolism via HIF1 $\alpha$ modulation. Cell Death Differ 21: 1805-1814, 2014.

21. Abu-Odeh M, Bar-Mag T, Huang H, Kim T, Salah Z, Abdeen SK, Sudol M, Reichmann D, Sidhu S, Kim PM, et al: Characterizing WW domain interactions of tumor suppressor WWOX reveals its association with multiprotein networks. J Biol Chem 289: 8865-8880, 2014.

22. Sałuda-Gorgul A, Seta K, Nowakowska M and Bednarek AK: WWOX oxidoreductase - substrate and enzymatic characterization. Z Naturforsch C 66: 73-82, 2011

23. Aqeilan RI, Hagan JP, de Bruin A, Rawahneh M, Salah Z, Gaudio E, Siddiqui H, Volinia S, Alder H, Lian JB, et al: Targeted ablation of the WW domain-containing oxidoreductase tumor suppressor leads to impaired steroidogenesis. Endocrinology 150: 1530-1535, 2009.

24. Aqeilan RI and Croce CM: WWOX in biological control and tumorigenesis. J Cell Physiol 212: 307-310, 2007.

25. Qin HR, Iliopoulos D, Semba S, Fabbri M, Druck T, Volinia S, Croce CM, Morrison CD, Klein RD and Huebner K: A role for the WWOX gene in prostate cancer. Cancer Res 66: 6477-6481, 2006.

26. Nunez MI, Rosen DG, Ludes-Meyers JH, Abba MC, Kil H, Page R, Klein-Szanto AJ, Godwin AK, Liu J, Mills GB, et al: WWOX protein expression varies among ovarian carcinoma histotypes and correlates with less favorable outcome. BMC Cancer 5: 64, 2005.

27. Kosla K, Pluciennik E, Kurzyk A, Jesionek-Kupnicka D, Kordek R, Potemski P and Bednarek AK: Molecular analysis of WWOX expression correlation with proliferation and apoptosis in glioblastoma multiforme. J Neurooncol 101: 207-213, 2011.

28. Kuroki T, Yendamuri S, Trapasso F, Matsuyama A, Aqeilan RI, Alder H, Rattan S, Cesari R, Nolli ML, Williams NN, et al: The tumor suppressor gene WWOX at FRA16D is involved in pancreatic carcinogenesis. Clin Cancer Res 10: 2459-2465, 2004.

29. Płuciennik E, Nowakowska M, Wujcicka WI, Sitkiewicz A, Kazanowska B, Zielińska E and Bednarek AK: Genetic alterations of WWOX in Wilms' tumor are involved in its carcinogenesis. Oncol Rep 28: 1417-1422, 2012.

30. Żelazowski MJ, Płuciennik E, Pasz-Walczak G, Potemski P, Kordek R and Bednarek AK: WWOX expression in colorectal cancer - a real-time quantitative RT-PCR study. Tumor Biol 32: 551-560, 2011.

31. Li YP, Wu CC, Chen WT, Huang YC and Chai CY: The expression and significance of WWOX and $\beta$-catenin in hepatocellular carcinoma. APMIS 121: 120-126, 2013.

32. Xiong Z, Hu S and Wang Z: Cloning of WWOX gene and its growth-inhibiting effects on ovarian cancer cells. J Huazhong Univ Sci Technolog Med Sci 30: 365-369, 2010.

33. Qu J, Lu W, Li B, Lu C and Wan X: WWOX induces apoptosis and inhibits proliferation in cervical cancer and cell lines. Int $\mathrm{J}$ Mol Med 31: 1139-1147, 2013.

34. Bednarek AK, Keck-Waggoner CL, Daniel RL, Laflin KJ, Bergsagel PL, Kiguchi K, Brenner AJ and Aldaz CM: WWOX, the FRA16D gene, behaves as a suppressor of tumor growth. Cancer Res 61: 8068-8073, 2001.

35. Gourley C, Paige AJ, Taylor KJ, Ward C, Kuske B, Zhang J, Sun M, Janczar S, Harrison DJ, Muir M, et al: WWOX gene expression abolishes ovarian cancer tumorigenicity in vivo and decreases attachment to fibronectin via integrin alpha3. Cancer Res 69: 4835-4842, 2009.

36. Nowakowska M, Pospiech K, Lewandowska U, PiastowskaCiesielska AW and Bednarek AK: Diverse effect of WWOX overexpression in HT29 and SW480 colon cancer cell lines. Tumor Biol 35: 9291-9301, 2014. 
37. Lewandowska U, Zelazowski M, Seta K, Byczewska M, Pluciennik E and Bednarek AK: WWOX, the tumor suppressor gene affected in multiple cancers. J Physiol Pharmacol 60 (Suppl 1): 47-56, 2009.

38. Płuciennik E, Kośla K, Wójcik-Krowiranda K, Bieńkiewicz A and Bednarek AK: The WWOX tumor suppressor gene in endometrial adenocarcinoma. Int J Mol Med 32: 1458-1464, 2013.

39. Pecorelli S: Revised FIGO staging for carcinoma of the vulva, cervix, and endometrium. Int J Gynaecol Obstet 105: 103-104, 2009.

40. Mo B, Vendrov AE, Palomino WA, DuPont BR, Apparao KB and Lessey BA: ECC-1 cells: A well-differentiated steroidresponsive endometrial cell line with characteristics of luminal epithelium. Biol Reprod 75: 387-394, 2006.

41. Pfaffl MW, Horgan GW and Dempfle L: Relative expression software tool (REST) for group-wise comparison and statistical analysis of relative expression results in real-time PCR. Nucleic Acids Res 30: e36, 2002.

42. Sakuragi N, Nishiya M, Ikeda K, Ohkouch T, Furth EE, Hareyama H, Satoh C and Fujimoto S: Decreased E-cadherin expression in endometrial carcinoma is associated with tumor dedifferentiation and deep myometrial invasion. Gynecol Oncol 53: 183-189, 1994

43. Płuciennik E, Kusińska R, Potemski P, Kubiak R, Kordek R and Bednarek AK: WWOX - the FRA16D cancer gene: Expression correlation with breast cancer progression and prognosis. Eur $\mathbf{J}$ Surg Oncol 32: 153-157, 2006.
44. Wang X, Chao L, Ma G, Chen L, Zang Y and Sun J: The prognostic significance of WWOX expression in patients with breast cancer and its association with the basal-like phenotype. J Cancer Res Clin Oncol 137: 271-278, 2011.

45. Spoelstra NS, Manning NG, Higashi Y, Darling D, Singh M, Shroyer KR, Broaddus RR, Horwitz KB and Richer JK: The transcription factor ZEB1 is aberrantly expressed in aggressive uterine cancers. Cancer Res 66: 3893-3902, 2006.

46. Singh M, Spoelstra NS, Jean A, Howe E, Tork ko KC, Clark HR, Darling DS, Shroyer KR, Horwitz KB, Broaddus RR, et al: ZEB1 expression in type I vs type II endometrial cancers: A marker of aggressive disease. Mod Pathol 21: 912-923, 2008.

47. Yan $\mathrm{H}$ and Sun Y: Evaluation of the mechanism of epithelialmesenchymal transition in human ovarian cancer stem cells transfected with a WW domain-containing oxidoreductase gene. Oncol Lett 8: 426-430, 2014.

48. Palumbo JS, Kombrinck KW, Drew AF, Grimes TS, Kiser JH, Degen JL and Bugge TH: Fibrinogen is an important determinant of the metastatic potential of circulating tumor cells. Blood 96: 3302-3309, 2000.

49. Sahni A, Arévalo MT, Sahni SK and Simpson-Haidaris PJ: The VE-cadherin binding domain of fibrinogen induces endothelial barrier permeability and enhances transendothelial migration of malignant breast epithelial cells. Int J Cancer 125: 577-584, 2009. 